\title{
DESAPROPRIAÇÃO URBANÍSTICA SANCIONATÓRIA E SUA UTILIZAÇÃO PRIORITÁRIẢ NA CONCRETIZAÇÃO DO DIREITO FUNDAMENTAL À MORADIA
}

\author{
Roberto Carvalho Veloso ${ }^{1}$ \\ João Simões Teixeira
}

RESUMO: O presente artigo tem por objetivo analisar a evolução do direito à propriedade privada, desde sua concepção liberal e ilimitada até seu condicionamento ao cumprimento de uma função social, estabelecido pela Constituição Federal de 1988 e pelo Código Civil de 2002, bem como averiguar a possibilidade de se priorizar a concretização do direito fundamental à moradia quando da realização das desapropriações por descumprimento da função social da propriedade, prescritas pelos artigos $182, \S 4^{\circ}$, inciso III da Constituição Federal e $8^{\circ}$ do Estatuto da Cidade. Para tanto, será utilizada a metodologia da revisão bibliográfica.

Palavra-Chave: Direito Constitucional; Direito Urbanístico; Direito à propriedade; Direito à moradia; Desapropriação urbanística.

\section{SANCTIONATORY URBANISTIC EXPROPRIATION AND ITS PRIORITY USE IN FUNDAMENTAL RIGHT TO HOUSING CONCRETIZATION}

\begin{abstract}
The present article aims to analyze the right to private property evolution, from its liberal and unlimited conception until its conditioning to the fulfillment of a social function, established by the Federal Constitution of 1988 and the Civil Code of 2002, as well as to ascertain the possibility of giving priority to the fundamental right to housing concretization when expropriations are performed for non-compliance with the property social function, prescribed by articles $182, \S 4^{\circ}$, III of the Federal Constitution and $8^{\circ}$ of the City Statute. For this purpose, the bibliographic review methodology will be used.
\end{abstract}

Keywords: Constitutional Law; Urbanistic Law; Right to property; Right to housing; Urbanistic expropriation.

\section{INTRODUÇÃO}

Busca-se no presente artigo analisar a evolução do direito à propriedade, desde sua concepção liberal e ilimitada, não submetido a nenhuma interferência estatal ou de terceiros,

\footnotetext{
${ }^{1}$ Doutor e Mestre em Direito pela UFPE (2008; 2002). Professor e Pesquisador da UniCEUMA. Professor Associado da UFMA. Coordenador do Mestrado em Direito da UFMA. Juiz Federal no Maranhão. Endereço: Universidade Federal do Maranhão, Pró-Reitoria de Graduação, Departamento de Direito. Campus I. BACANGA, 65000000 - São Luís, MA - Brasil. Telefone: (98) 32178433. velosorc@uol.com.br

${ }^{2}$ Mestrando em Direito pela UFMA. Graduado em Direito pela UFC (2014). Procurador do Município de São Luís. Endereço: Av. dos Holandeses, qd. 16, nº 04, Ponta D’Areia, ed. Lakeside, 65077357 - São Luís, MA Brasil. Telefone (85) 996339997 j.simoes.t@gmail.com
} 
até seu condicionamento ao cumprimento da função social, estabelecido pela Constituição Federal de 1988 e pelo Código Civil de 2002.

Além desse objetivo geral, têm-se, ainda, como objetivo específico averiguar a possibilidade da concretização do direito fundamental à moradia ser priorizada, no momento da efetivação das desapropriações por descumprimento da função social da propriedade, estabelecidas no artigo 182, $\S 4^{\circ}$, inciso III da Constituição Federal de 1988 e no artigo $8^{\circ}$ do Estatuto da Cidade, Lei n ${ }^{\circ} 10.257$, de 10 de julho de 2001.

Para a realização desses objetivos será utilizada a metodologia da revisão bibliográfica, a partir do referencial teórico de Rosenvald (2019) e Sundfeld (2013).

Para o desenvolvimento da pesquisa, a partir dos objetivos a serem alcançados, formulou-se o seguinte problema: em que medida a desapropriação urbanística sancionatória tem amparo constitucional e legal?

O conceito liberal clássico de propriedade privada, qual seja, de direito natural, fundamental, absoluto, perpétuo e sagrado tem origem na França revolucionária de 1789, sustentando-se na doutrina de grandes filósofos iluministas, tais como Locke, Voltaire, Rousseau e Montesquieu. Ademais, restou positivado em diversas normas da época, como a Declaração de Direitos do Homem e do Cidadão de 1789, o Código Civil francês de 1804 e o Código Civil italiano de 1865.

Ao longo do tempo, entretanto, referido conceito sofreu significativa relativização, mormente com o surgimento do Estado Social, no início do século XX, e com o fenômeno da constitucionalização do Direito Civil.

A desapropriação por descumprimento da função social da propriedade - ou desapropriação urbanística sancionatória - configura exemplo da relativização do caráter absoluto da propriedade. Embora represente hipótese excepcional, tem previsão expressa na Carta Magna, além de estar regulamentada no Estatuto da Cidade.

Busca-se, portanto, analisar de forma detalhada a evolução do direito à propriedade, bem como averiguar a viabilidade de se priorizar a concretização do direito fundamental à moradia quando da realização de desapropriações por descumprimento da função social da propriedade.

\section{A EVOLUÇÃO HISTÓRIA DO DIREITO À PROPRIEDADE: DO CARÁTER ABSOLUTO À OBEDIÊNCIA À FUNÇÃO SOCIAL}


Há três coisas que, desde as mais antigas eras, encontram-se fundadas e solidamente estabelecidas nas sociedades grega e itálica: a religião doméstica, a família e o direito de propriedade (COULANGES, 2006, p. 52).

A propriedade coletiva tribal, ou, mais amplamente, grupal precedeu à propriedade individual. Porém não fora nunca comunística (de todos); fora do grupo, distribuído o uso, segundo critérios também de interesse grupal (MIRANDA, 2002, p. 29).

Com raiz histórica no direito romano, em que predominava uma conotação individualista, a propriedade é a plenitude do direito sobre a coisa; por isso, as diversas faculdades que nela se distinguem são apenas manifestações daquela plenitude (DINIZ, 2014, pp. $125 ; 132)$.

Sua consagração como direito fundamental remonta às revoluções políticas do século XVIII, notadamente à Revolução Francesa de 1789 e à Independência dos Estados Unidos, em 1776. Tal período marca a queda do absolutismo na França, a positivação dos ideais da classe burguesa em códigos e constituições, bem como o surgimento do Estado Liberal ou Estado de Direito.

Nascem, ademais, os direitos fundamentais de primeira dimensão, tidos como garantias de uma postura negativa, não interventora por parte do Estado, em homenagem ao valor supremo da liberdade individual. Dentre esses, destaca-se o direito à propriedade privada, idealizado como um direito natural, ou seja, inerente à natureza humana, além de absoluto, perpétuo e sagrado.

Leciona Fachin (2003, p. 288) que a disciplina jurídica da propriedade nasce do artigo 544 do Código Civil francês de $1804^{3}$, que garantia o exercício de tal direito da forma mais ampla possível.

No Brasil, a Constituição Imperial de $1824^{4}$, a Constituição Republicana de $1891^{5}$ e o Código Civil de $1916^{6}$ reproduzem a concepção jusnaturalista e iluminista de propriedade, qual seja, de direito fundamental absoluto, que não está sujeito às intromissões do Estado.

\footnotetext{
${ }^{3}$ 544. La propriété est le droit de jouir et disposer des choses de la manière la plus absolue, pourvu qu'on n'en fasse pas un usage prohibé par le lois ou par les réglemens.

${ }^{4}$ Art. 179. A inviolabilidade dos Direitos Civis, e Politicos dos Cidadãos Brazileiros, que tem por base a liberdade, a segurança individual, e a propriedade, é garantida pela Constituição do Imperio, pela maneira seguinte.

XXII. É garantido o Direito de Propriedade em toda a sua plenitude. Se o bem publico legalmente verificado exigir o uso, e emprego da Propriedade do Cidadão, será elle préviamente indemnisado do valor della. A Lei marcará os casos, em que terá logar esta unica excepção, e dará as regras para se determinar a indemnisação.
} 
Ao longo do século XIX, contudo, referida concepção de propriedade passa a sofrer diversas críticas, em especial dos trabalhadores, em virtude das péssimas condições de trabalho a que estavam submetidos, bem como dos adeptos do socialismo.

Nesse contexto, destaca Hobsbawm:

\begin{abstract}
A situação dos trabalhadores pobres, e especialmente do proletariado industrial que formava seu núcleo, era tal que a rebelião era não somente possível mas virtualmente compulsória. Nada foi mais inevitável na primeira metade do século XIX do que o aparecimento dos movimentos trabalhista e socialista, assim como a intranquilidade revolucionária das massas. A revolução de 1848 foi sua consequência direta. Entre 1815 e 1848, nenhum observador consciente podia negar que a situação dos trabalhadores pobres era assustadora (HOBSBAWM, 2008, p. 285).
\end{abstract}

Assim, no século XX, a Constituição Mexicana de 1917 e a Constituição da República de Weimar de 1919 simbolizaram o surgimento do Estado Social - Estado de bemestar social ou Welfare State -, marcado pela consagração dos direitos sociais ou direitos fundamentais de segunda dimensão, que exigiam uma conduta ativa por parte do Estado, de modo a assegurar, a título exemplificativo, o acesso à saúde, à educação, à moradia e aos direitos trabalhistas.

Desse momento em diante, a igualdade apenas formal ou política torna-se sensivelmente insatisfatória. Reivindica-se uma igualdade plena, material, econômica, apta a proporcionar a todos os indivíduos uma vida digna.

Nas palavras de Bonavides:

Conduzido para fora das esferas abstratas, o princípio da igualdade,
inarredavelmente atado à doutrina do Estado social, já não pode ignorar o primado
do fator ideológico nem tampouco as demais considerações de natureza axiológica.
Ideologia e valores entram assim a integrar o conceito da igualdade, provocando
uma crise para a velha igualdade jurídica do Estado de Direito. Ela que nascera
ideológica, levantada nos braços do direito natural, se despolitizou num segundo
momento, ao adquirir uma neutralidade de aparência, a qual apenas subsistiu
enquanto pôde subsistir o antigo Estado de Direito da burguesia liberal e capitalista
do século XIX (BONAVIDES, 2018, p. 579).

Assim, o processo de relativização do conceito de propriedade consagra-se, no Brasil, com a promulgação da Constituição Federal de 1988, a qual estabelece, em seu artigo

\footnotetext{
${ }^{5}$ Art. 72. A Constituição assegura a brasileiros e a estrangeiros residentes no paiz a inviolabilidade dos direitos concernentes á liberdade, á segurança individual e á propriedade, nos termos seguintes:

$\S 17$. O direito de propriedade mantem-se em toda a sua plenitude, salvo a desapropriação por necessidade, ou utilidade pública, mediante indemnização prévia.

${ }^{6}$ Art. 524. A lei assegura ao proprietário o direito de usar, gozar e dispor de seus bens, e de reave-los do poder de quem quer que injustamente os possua.
} 
$5^{\circ}$, XXII, ser "garantido o direito de propriedade", ressalvando, no inciso XXIII, que "a propriedade atenderá a sua função social” e, no XXIV, que "a lei estabelecerá o procedimento para desapropriação por necessidade ou utilidade pública, ou por interesse social, mediante justa e prévia indenização em dinheiro".

Acrescenta-se que tanto a propriedade privada quanto a função social da propriedade foram alçadas à condição de princípios da ordem econômica, conforme artigo 170, incisos II e III, respectivamente, da Constituição Cidadã.

A respeito da função social da propriedade, adverte Carvalho Filho:

\begin{abstract}
Nas entrelinhas do dispositivo, é forçoso reconhecer a veiculação de certa ameaça aos proprietários, como se estes devessem ser advertidos de que, sem o atendimento à função social, não se lhes poderia garantir o direito de propriedade. Quer dizer: a garantia do direito de propriedade (inciso XXII) só tem aplicabilidade concreta se conjugada com o fim social da propriedade (inciso XXIII). Esta, pois, é a outra perspectiva do instituto (CARVALHO FILHO, 2003, p. 170).
\end{abstract}

Logo, o Código Beviláqua, que fora fruto do individualismo e do dogma da vontade particular e tinha como figuras centrais a propriedade e o contrato, sofre uma vasta alteração com o advento da Carta Magna de 1988, passando a ser interpretado à luz desta, processo que se convencionou denominar de constitucionalização do direito civil ou publicização do direito privado (NANNI, 2001, pp. 162-163).

Com o advento do Código Civil de 2002, passou a existir, nos termos do artigo $2.035^{7}$, menção expressa ao instituto da função social da propriedade, sendo consideradas matéria de ordem pública as normas que lhe dizem respeito.

Atualmente, é inegável o reconhecimento de que a propriedade tem sofrido, ao longo da evolução de sua concepção, um contínuo processo de publicização, cujo postulado maior reside na qualificação que passou a ostentar contemporaneamente e no papel que agora lhe cabe desempenhar na sociedade (CARVALHO FILHO, 2003, p. 173).

\title{
3 A DESAPROPRIAÇÃO COMO MECANISMO DE INTERVENÇÃO NA PROPRIEDADE PRIVADA E INSTRUMENTO DE DIREITO URBANÍSTICO
}

\footnotetext{
${ }^{7}$ Art. 2.035. A validade dos negócios e demais atos jurídicos, constituídos antes da entrada em vigor deste Código, obedece ao disposto nas leis anteriores, referidas no art. 2.045 , mas os seus efeitos, produzidos após a vigência deste Código, aos preceitos dele se subordinam, salvo se houver sido prevista pelas partes determinada forma de execução.

Parágrafo único. Nenhuma convenção prevalecerá se contrariar preceitos de ordem pública, tais como os estabelecidos por este Código para assegurar a função social da propriedade e dos contratos.
} 
A desapropriação é o procedimento administrativo por meio do qual o Poder Público ou seus delegados, mediante prévia declaração de necessidade pública, utilidade pública ou interesse social, impõe ao proprietário a perda de um bem, substituindo-o em seu patrimônio por justa indenização. (DI PIETRO, 2014, p. 166).

É a mais drástica das formas de manifestação do poder de império, ou seja, da soberania interna do Estado no exercício de seu domínio eminente sobre todos os bens existentes no território nacional. Mas o poder expropriatório, conquanto discricionário nas opções de utilidade pública e de interesse social, só é legitimamente exercitável nos limites traçados pela Constituição e nos casos expressos em lei, observado o devido procedimento legal (MEIRELLES, 2012, p. 664).

Dá-se, via de regra, por necessidade ou utilidade pública, conforme Decreto $\mathrm{n}^{\circ} 3.365$, de 21 de junho de 1941, ou por interesse social, nos termos da Lei $n^{\circ} 4.132$, de 10 de setembro de 1962. Dentre os dispositivos dessa referida norma, destacam-se os artigos $1^{\circ}$ e $2^{\circ}$, inciso $\mathrm{V}$, os quais estabelecem:

Art. $1^{\circ}$ A desapropriação por interesse social será decretada para promover a justa distribuição da propriedade ou condicionar o seu uso ao bem estar social, na forma do art. 147 da Constituição Federal.

Art. $2^{\circ}$ Considera-se de interesse social:

(...)

$\mathrm{V}$ - a construção de casa populares;

Ademais, embora seja opção excepcional, encontra-se expressamente prevista, no artigo 182, § $4^{\circ}$, inciso III da Constituição Federal, a hipótese de desapropriação por descumprimento da função social da propriedade, restringindo-se a imóveis urbanos não edificados, subutilizados ou não utilizados. É de competência municipal exclusiva, condicionando-se ao descumprimento de determinação de parcelamento ou edificação compulsórios, em um primeiro momento, e de pagamento de imposto predial territorial urbano - IPTU progressivo no tempo, posteriormente, como se vê:

Art. 182. A política de desenvolvimento urbano, executada pelo Poder Público municipal, conforme diretrizes gerais fixadas em lei, tem por objetivo ordenar o pleno desenvolvimento das funções sociais da cidade e garantir o bem-estar de seus habitantes.

$\S 4^{\circ}$ É facultado ao Poder Público municipal, mediante lei específica para área incluída no plano diretor, exigir, nos termos da lei federal, do proprietário do solo urbano não edificado, subutilizado ou não utilizado, que promova seu adequado aproveitamento, sob pena, sucessivamente, de:

I - parcelamento ou edificação compulsórios;

II - imposto sobre a propriedade predial e territorial urbana progressivo no tempo; 
III - desapropriação com pagamento mediante títulos da dívida pública de emissão previamente aprovada pelo Senado Federal, com prazo de resgate de até dez anos, em parcelas anuais, iguais e sucessivas, assegurados o valor real da indenização e os juros legais.

A desapropriação sancionatória também pode ser denominada desapropriação extraordinária, em razão da sua forma de indenizar, e tem como fundamento a prática de uma ilegalidade, materializada no descumprimento da função social da propriedade, cumulada com um interesse social (MARINELA, 2013, p. 925).

Entende-se por propriedade não edificada a área urbana nua, sem qualquer benfeitoria ou edificação, desde que se localize em região atingida pelo Plano Diretor, enquanto o imóvel não utilizado é aquele que se encontra abandonado ou mesmo não habitado, incluídas as construções paralisadas e as destruídas (LEAL, 2013, p. 4.038).

A função social da propriedade é imprescindível à manutenção de condições mínimas para a convivência social (DINIZ, 2014, p. 127). A disponibilidade total, como estoque, ou como amadorismo de algumas pessoas que encontram prazer em acumular coisas, esbarra na necessidade do uso das coisas em favor da comunidade, concluindo que deixa de ser lógico garantir a um proprietário um direito que ele próprio não quer exercer (KICH, 2004, p. 115).

Por seu caráter sancionatório e sua abrangência limitada às propriedades urbanas, referido procedimento também é denominado desapropriação sancionatória urbanística, sendo regulamentado pelo Estatuto da Cidade, Lei Federal n ${ }^{\circ}$ 10.257, de 10 de julho de 2001, que estabelece as diretrizes gerais da política urbana.

Em seu artigo $5^{\circ}$, a referida lei estipula disposições específicas a respeito do parcelamento, edificação ou utilização compulsórios da propriedade, definindo prazo mínimo

\footnotetext{
${ }^{8}$ Art. $5^{\circ}$ Lei municipal específica para área incluída no plano diretor poderá determinar o parcelamento, a edificação ou a utilização compulsórios do solo urbano não edificado, subutilizado ou não utilizado, devendo fixar as condições e os prazos para implementação da referida obrigação.

$\S 1^{\circ}$ Considera-se subutilizado o imóvel:

I - cujo aproveitamento seja inferior ao mínimo definido no plano diretor ou em legislação dele decorrente; II - (VETADO)

$\S 2^{\circ} \mathrm{O}$ proprietário será notificado pelo Poder Executivo municipal para o cumprimento da obrigação, devendo a notificação ser averbada no cartório de registro de imóveis.

$\S 3^{\circ}$ A notificação far-se-á:

I - por funcionário do órgão competente do Poder Público municipal, ao proprietário do imóvel ou, no caso de este ser pessoa jurídica, a quem tenha poderes de gerência geral ou administração;

II - por edital quando frustrada, por três vezes, a tentativa de notificação na forma prevista pelo inciso I.

$\S 4^{\circ}$ Os prazos a que se refere o caput não poderão ser inferiores a:

I - um ano, a partir da notificação, para que seja protocolado o projeto no órgão municipal competente;

II - dois anos, a partir da aprovação do projeto, para iniciar as obras do empreendimento.
} 
de um ano, a contar da notificação do proprietário, para que seja protocolado projeto de parcelamento, edificação ou utilização, bem como de dois anos, a partir da aprovação do projeto, para início das obras do empreendimento.

No que diz respeito à cobrança de IPTU progressivo, a ser realizada nas hipóteses de descumprimento das condições e dos prazos acima explanados, deve ser feita mediante a majoração da alíquota, por cinco anos consecutivos, a qual será fixada em lei específica, não excederá ao dobro do valor referente ao ano anterior nem ultrapassará o patamar máximo de $15 \%$, sendo vedada, ademais, a concessão de isenções ou anistias, nos termos do $\operatorname{artigo} 7^{\circ}$ do Estatuto 9 .

Persistindo o descumprimento ao longo dos cinco anos, conforme artigo $8^{\mathrm{o}}{ }^{10}$, pode o Município desapropriar o imóvel com pagamento em títulos da dívida pública, de prévia aprovação pelo Senado Federal, resgatáveis em até dez anos, em prestações anuais, iguais e sucessivas, assegurados juros de $6 \%$ ao ano, assim como o valor real da indenização.

$\S 5^{\circ}$ Em empreendimentos de grande porte, em caráter excepcional, a lei municipal específica a que se refere o caput poderá prever a conclusão em etapas, assegurando-se que o projeto aprovado compreenda o empreendimento como um todo.

${ }^{9}$ Art. $7^{\circ}$ Em caso de descumprimento das condições e dos prazos previstos na forma do caput do art. $5^{\circ}$ desta Lei, ou não sendo cumpridas as etapas previstas no $\S 5^{\circ}$ do art. $5^{\circ}$ desta Lei, o Município procederá à aplicação do imposto sobre a propriedade predial e territorial urbana (IPTU) progressivo no tempo, mediante a majoração da alíquota pelo prazo de cinco anos consecutivos.

$\S 1^{\circ} \mathrm{O}$ valor da alíquota a ser aplicado a cada ano será fixado na lei específica a que se refere o caput do art. $5^{\circ}$ desta Lei e não excederá a duas vezes o valor referente ao ano anterior, respeitada a alíquota máxima de quinze por cento.

$\S 2^{\circ}$ Caso a obrigação de parcelar, edificar ou utilizar não esteja atendida em cinco anos, o Município manterá a cobrança pela alíquota máxima, até que se cumpra a referida obrigação, garantida a prerrogativa prevista no art. $8^{\circ}$.

$\S 3^{\circ}$ É vedada a concessão de isenções ou de anistia relativas à tributação progressiva de que trata este artigo.

${ }^{10}$ Art. $8^{\circ}$ Decorridos cinco anos de cobrança do IPTU progressivo sem que o proprietário tenha cumprido a obrigação de parcelamento, edificação ou utilização, o Município poderá proceder à desapropriação do imóvel, com pagamento em títulos da dívida pública.

$\S 1^{\circ}$ Os títulos da dívida pública terão prévia aprovação pelo Senado Federal e serão resgatados no prazo de até dez anos, em prestações anuais, iguais e sucessivas, assegurados o valor real da indenização e os juros legais de seis por cento ao ano.

$\S 2^{\circ} \mathrm{O}$ valor real da indenização:

I - refletirá o valor da base de cálculo do IPTU, descontado o montante incorporado em função de obras realizadas pelo Poder Público na área onde o mesmo se localiza após a notificação de que trata o $§ 2^{\circ}$ do art. $5 \%$ desta Lei;

II - não computará expectativas de ganhos, lucros cessantes e juros compensatórios.

$\S 3^{\circ}$ Os títulos de que trata este artigo não terão poder liberatório para pagamento de tributos.

$\S 4^{\circ} \mathrm{O}$ Município procederá ao adequado aproveitamento do imóvel no prazo máximo de cinco anos, contado a partir da sua incorporação ao patrimônio público.

$\S 5^{\circ} \mathrm{O}$ aproveitamento do imóvel poderá ser efetivado diretamente pelo Poder Público ou por meio de alienação ou concessão a terceiros, observando-se, nesses casos, o devido procedimento licitatório.

$\S 6^{\circ}$ Ficam mantidas para o adquirente de imóvel nos termos do $\S 5^{\circ}$ as mesmas obrigações de parcelamento, edificação ou utilização previstas no art. $5^{\circ}$ desta Lei. 
Em seguida, o Município é que passa a estar obrigado a dar adequado aproveitamento ao imóvel, no prazo de cinco anos, sendo permitido, por meio de licitação, a alienação ou concessão a terceiros.

Nessa toada, tem-se que urbanismo é o conjunto de medidas estatais destinadas a organizar os espaços habitáveis, de modo a propiciar melhores condições de vida ao homem na comunidade (MEIRELLES, 2008, p. 522).

Seria um anacronismo pensar em direito urbanístico anterior ao século XX. Esse direito contrapôs-se ao direito civil clássico ao deslocar do âmbito puramente individual para o estatal as decisões básicas quanto ao destino das propriedades urbanas (SUNDFELD, 2009, p. 46).

Concebido, inicialmente, como a arte de embelezar a cidade, o urbanismo já não pode estar submetido exclusivamente às regras de esteticismo gratuito, sendo, por sua essência, de ordem funcional (SILVA, 2010, p. 30).

O direito urbanístico exige que toda e qualquer alteração no ambiente urbano seja previamente planejada e projetada, sendo os planos elaborados por técnicos, ainda que sejam aprovados por políticos, com o intuito de garantir que a construção da cidade obedeça aos princípios e métodos do urbanismo (PINTO, 2011, p. 200).

Alerta Sundfeld (2009, pp. 56-57) que referido direito, justamente por decorrer do que considera uma visão totalizante de mundo - e de muito coerentemente tratar o urbanismo como função pública -, sujeita-se ao risco nada desprezível de descambar para o totalitarismo estatal. Destaca ainda que "se é verdade que a própria existência do direito urbanístico é uma reação ao crescimento urbano sem ordem e ao caos gerado pelas atuações individuais, ele não pode traduzir-se na substituição do caos privado pelo caos estatal”.

Contudo, o próprio Sundfeld (2009, p. 57) leciona que, contra esse risco, duas foram as reações das diretrizes gerais do Estatuto da Cidade, quais sejam, a afirmação do princípio instrumental da gestão democrática e o reconhecimento da ação privada ${ }^{11}$.

\footnotetext{
${ }^{11}$ Art. $2^{\circ}$ A política urbana tem por objetivo ordenar o pleno desenvolvimento das funções sociais da cidade e da propriedade urbana, mediante as seguintes diretrizes gerais: (...)

II - gestão democrática por meio da participação da população e de associações representativas dos vários segmentos da comunidade na formulação, execução e acompanhamento de planos, programas e projetos de desenvolvimento urbano;

III - cooperação entre os governos, a iniciativa privada e os demais setores da sociedade no processo de urbanização, em atendimento ao interesse social;
} 
Assim, não mais se concebe o exercício do direito à propriedade de forma absolutamente livre, insubmissível a qualquer interferência por parte do Estado. Não se aceita, à luz da necessidade de cumprimento de sua função social, que a propriedade permaneça não edificada, subutilizada ou não utilizada.

Ademais, a título exemplificativo, é inadmissível, por óbvio, que o direito à propriedade seja exercido em prejuízo ao direito ao meio ambiente ecologicamente equilibrado, o que violaria o artigo 225 da Constituição Federal de 1988, ou de modo a permitir a exploração de trabalho escravo, hipótese, inclusive, que daria ensejo à expropriação da propriedade, sem direito a indenização e sem prejuízo das demais sanções legais.

Tem-se, dessa maneira que, conforme estabelece a Constituição Alemã de 1949, Lei Fundamental de Bonn, em seu artigo 14, parágrafo $2^{\circ}$, "a propriedade obriga" e "seu uso deve servir, ao mesmo tempo, ao bem comum".

A respeito dos direitos e deveres referentes à propriedade, esclarece Leal:

[...] sob a ótica dogmático-jurídica mais tradicional, é inerente à propriedade um conteúdo positivo, circunscrito pelos chamados limites positivos que fixam o elenco de poderes e faculdades do titular do direito e o alcance do respectivo exercício, indicando até onde aquele pode ir na realização de tais poderes e faculdades. De outra banda, há um conteúdo negativo, circunscrito pelos limites e limitações negativas que estabelecem até onde podem ocorrer ingerências e tangenciamentos de terceiros em relação ao direito alheio, quais os poderes e faculdades de que não dispõe seu titular e aonde esse não pode ir no exercício do direito (LEAL, 1998, p. 126).

Destaca Pereira (2014, p. 58) que a propriedade individual vigente em nossos dias, exprimindo-se embora em termos clássicos e usando a mesma terminologia, não conserva, todavia, conteúdo idêntico ao de suas origens históricas. É certo que se reconhece ao dominus o poder sobre a coisa; é exato que o domínio enfeixa os mesmos atributos originários - ius utendi, fruendi et abutendi. Mas é inegável também que essas faculdades suportam evidentes restrições legais, tão frequentes e severas, que se vislumbra a criação de novas noções. São restrições e limitações tendentes a coibir abusos e cuja finalidade é impedir que o exercício do direito de propriedade se transforme em instrumento de dominação.

A respeito da inevitabilidade da fixação de sanções aos proprietários que descumpram seus deveres, citam-se os ensinamentos de Kelsen (1998, p. 19), para quem é duvidoso que seja sequer possível uma distinção entre ordens sociais sancionadas e ordens sociais não sancionadas, razão pela qual a única distinção de ordens sociais a se ter em conta 
não reside em que umas definem sanções e outras não, mas nas diferentes espécies de sanções que estatuem.

\section{CARÁTER EXCEPCIONAL DA DESAPROPRIAÇÃO URBANÍSTICA E SUA UTILIZAÇÃO PRIORITÁRIA NA CONCRETIZAÇÃO DO DIREITO FUNDAMENTAL À MORADIA}

A Declaração Universal de Direitos Humanos ${ }^{12}$, proclamada pela Assembleia Geral das Nações Unidas, em Paris, em 10 de dezembro de 1948, por meio da Resolução 217-A, em resposta às atrocidades cometidas durante a $2^{\mathrm{a}}$ Guerra Mundial, estabelece, em seu artigo $\mathrm{XXV}$, que todo ser humano tem direito a um padrão de vida capaz de assegurar-lhe, e a sua família, uma habitação, entre outros direitos essenciais.

Por sua vez, o Pacto Internacional dos Direitos Econômicos, Sociais e Culturais ${ }^{13}$, que forma, em conjunto com o Pacto Internacional dos Direitos Civis e Políticos e com a referida Declaração Universal de Direitos Humanos, a Carta Internacional dos Direitos Humanos, reconhece o direito de toda pessoa a uma moradia adequada.

Também visando à garantia do direito à moradia, a Convenção sobre a Eliminação de Todas as Formas de Discriminação contra a Mulher, de $1979^{14}$, incorporada ao ordenamento jurídico nacional por meio do Decreto $\mathrm{n}^{\circ} 4.377$, de 13 de setembro de 2002, garante às mulheres "condições de vida adequadas", inclusive no que diz respeito à habitação.

A Constituição Cidadã, por sua vez, por meio de alteração ao seu artigo $6^{\circ}$, introduzida pela emenda $\mathrm{n}^{\mathrm{o}} 26$, de 14 de fevereiro de 2000 , conferiu status de direito fundamental social ao direito à moradia.

Nesse ínterim, nas palavras de Silva:

\footnotetext{
${ }^{12}$ Artigo XXV. Todo ser humano tem direito a um padrão de vida capaz de assegurar-lhe, e a sua família, saúde e bem-estar, inclusive alimentação, vestuário, habitação, cuidados médicos e os serviços sociais indispensáveis, e direito à segurança em caso de desemprego, doença, invalidez, viuvez, velhice ou outros casos de perda dos meios de subsistência em circunstâncias fora de seu controle.

${ }^{13}$ Art. 11. 1. Os Estados Partes do presente Pacto reconhecem o direito de toda pessoa a um nível de vida adequando para si próprio e sua família, inclusive à alimentação, vestimenta e moradia adequadas, assim como a uma melhoria contínua de suas condições de vida. Os Estados Partes tomarão medidas apropriadas para assegurar a consecução desse direito, reconhecendo, nesse sentido, a importância essencial da cooperação internacional fundada no livre consentimento.

${ }^{14}$ Art. 14. 2. Os Estados-Partes adotarão todas as medidas apropriadas para eliminar a discriminação contra a mulher nas zonas rurais a fim de assegurar, em condições de igualdade entre homens e mulheres, que elas participem no desenvolvimento rural e dele se beneficiem, e em particular assegurar-lhes-ão o direito a: h) gozar de condições de vida adequadas, particularmente nas esferas da habitação, dos serviços sanitários, da eletricidade e do abastecimento de água, do transporte e das comunicações.
} 


\begin{abstract}
A Constituição de 1988 não chegou a uma declaração tão precisa do direito à moradia. Fê-lo, porém, através da Emenda Constitucional 26/2000, pela sua inclusão entre os direitos sociais previstos no seu art. 6a e pela imposição ao Poder Público (União, Estados, Distrito Federal e Municípios) da competência-dever de satisfazer esse direito-necessidade humana. Assim é que conferiu à União a competência para instituir diretrizes para a habitação (art. 21, XX) e estatuiu a competência comum da União, dos Estados, do Distrito Federal e dos Municípios para "promover programas de construção de moradias e a melhoria das condições habitacionais e de saneamento básico" (art. 23, EX). A contrapartida dessa competência é precisamente o direito de todos à moradia, incumbindo, assim, àquelas entidades do Poder Público promover tais providências para a satisfação desse direito em relação à população que, por deficiência econômica, não pode provê-lo por seus próprios meios (SILVA, 2000, p. 376).
\end{abstract}

Por sua vez, estabelece o Código Civil brasileiro, em seu artigo 1.228, caput, ser a propriedade o direito de usar, gozar e dispor da coisa, além de reavê-la do poder de quem quer que injustamente a possua ou detenha, acrescentando, em seu $\S 1^{\circ}$, que referida faculdade deve ser exercida em consonância com as finalidades econômicas e sociais da propriedade, atentando, ademais, para a necessidade de preservação do meio ambiente.

Assim, ressalta-se que o direito à moradia difere do direito à propriedade pelo fato de aquele conter a previsão de que todos os indivíduos possuem o direito a uma propriedade digna para residir, enquanto este, atento mais à liberdade individual que à justiça social, garante a inviolabilidade da propriedade contra arbitrariedades do Estado ou de terceiros, mas apenas para os que gozam do privilégio de terem obtido uma propriedade.

Defender o direito à moradia, portanto, significa perceber que além do direito de propriedade existe também o direito à propriedade, como uma das possíveis concretizações do direito fundamental social à moradia. Ao lado de uma perspectiva estática existe uma perspectiva dinâmica, do mesmo modo que ao lado da proteção de quem já possui - proteção do ter -, o Direito passa a se preocupar com a proteção de quem ainda não tem, mas que aos bens procura ter acesso - proteção do ser, da esperança. Ao lado da manutenção do que é, a viabilização do vir a ser (NETO, 2013, p. 3868).

Concretamente, é por meio da propriedade que a pessoa se sente realizada, principalmente quando tem um bem próprio para a sua residência. Nesse plano, a morada da pessoa é o local propício para a perpetuação da sua dignidade. Em verdade, o direito à vida digna, dentro da ideia de um patrimônio mínimo, começa com a propriedade da casa própria (TARTUCE, 2014, p. 90).

Apesar da imprescindibilidade de uma moradia adequada para a concretização de uma vida digna, estudo elaborado pela Associação Brasileira de Incorporadoras Imobiliárias 
(Abrainc), em parceria com a Fundação Getúlio Vargas (FGV), aponta que, em dez anos, de 2007 a 2017, o déficit habitacional brasileiro cresceu 7\%, alcançando o patamar desolador de 7,78 milhões de unidades habitacionais, sendo ele majoritariamente urbano ( $85 \%$ do total), conforme pesquisa realizada pelo Instituto de Pesquisa Econômica Aplicada (Ipea), elaborada com base na Pesquisa Nacional por Amostra de Domicílios (PNAD-2012).

Aludida desigualdade é ainda mais alarmante quando cotejada com os dados disponibilizados pelo Censo de 2010, do Instituto Brasileiro de Geografia e Estatística (IBGE), segundo os quais o país possui mais de seis milhões de domicílios vagos, número que à época era superior ao déficit habitacional brasileiro, que estava em 5,8 milhões de moradias, existindo, portanto, mais casa sem gente do que gente sem casa.

Nesse contexto, destacam-se as lições de Holanda (1995, p. 61) a respeito da formação da sociedade brasileira, a qual classifica como de origem nitidamente personalista, razão pela qual conclui ser compreensível que, no país, os simples vínculos de pessoa a pessoa, independentes e até exclusivos de qualquer tendência para a cooperação autêntica entre os indivíduos, tenham sido quase sempre os mais decisivos.

Ressalta-se que a desapropriação sancionatória urbanística, que ocorrerá em virtude da penalidade ao descumprimento da função social da propriedade somada ao interesse social no caso concreto, deve atentar prioritariamente à concretização desse direito social fundamental, qual seja, o acesso à moradia.

Embora não se possa, à luz do ordenamento jurídico atual, exigir de modo vinculante que o Município dê essa destinação ao imóvel desapropriado, pode-se defender que essa seja a prioridade do ente público, em virtude da imprescindibilidade da concretização desse direito à garantia de uma vida digna.

Ademais, a utilização do instrumento da desapropriação urbanística - desde que respeitado seu caráter excepcional e condicionado ao manifesto desrespeito a todas as etapas elencadas nos artigos $5^{\circ}, 6^{\circ}, 7^{\circ}$ e $8^{\circ}$ do Estatuto da Cidade - com o intuito de proporcionar residência digna aos que desta não usufruem não relativiza ou enfraquece o direito à propriedade privada, mas, ao contrário, o fortalece.

Nesse ínterim, destacam-se as lições de Rosenvald:

Eliminar a diversidade e a tolerância, anular o individual pelo coletivo e fragilizar a propriedade em nome de um viés igualitário são as primeiras formas de eliminar as demais liberdades: política, civil e de pensamento.

(...) 
Ao contrário do privilégio, a propriedade privada não é uma afronta ao princípio da solidariedade. A exclusão social vivenciada no Brasil não resulta da existência de propriedade, mas de sua insuficiência e da ausência de uma ação política firme no sentido de estender a condição de proprietários em prol daqueles que hoje estão juridicamente alheios ao sistema de titularidades (ROSENVALD, 2019, p. 591).

Assim, o acesso à propriedade significa mais do que acesso à moradia, pois impõe acesso à saúde, educação e cultura. Se "os males da propriedade se curam com mais propriedade" e o direito civil é o direito das pessoas, a propriedade é inexoravelmente um instrumento para uma vida digna (ROSENVALD, 2019, p. 591).

Ademais, a propriedade particular oferece o único refúgio seguro de uma pessoa contra o mundo público comum. "Um lugar só nosso, no qual podemos nos esconder" (ARENDT, 2007, pp. 80-81).

\section{CONSIDERAÇÕES FINAIS}

Por meio da presente pesquisa, conclui-se, inicialmente, que o direito à propriedade privada se consolidou como um direito fundamental, oponível ao Estado, ao final do século XVIII, mormente com a eclosão da Revolução Francesa, em 1789. À época, foi concebido como direito absoluto, sagrado e perpétuo, que não admitia intervenções estatais ou de terceiros, tendo sido aludida concepção introduzida no ordenamento jurídico brasileiro.

Posteriormente, aludido conceito fora relativizado, notadamente no início do século XX, com o surgimento do Estado Social e dos direitos sociais ou direitos fundamentais de segunda dimensão. Referida transição deu-se, no Brasil, de forma lenta e gradual, passando pela publicação do Decreto $\mathrm{n}^{\circ} 3.365$, de 21 de junho de 1941 e da Lei ${ }^{\circ} 4.132$, de 10 de setembro de 1962, e consolidando-se com o advento da Constituição Federal de 1988 e do Código Civil de 2002.

Nesse contexto de relativização do outrora absoluto conceito de propriedade privada, estabeleceu a Carta Magna, em seu artigo 182, $\S 4^{\circ}$, inciso III, assim como o Estatuto da Cidade, em seu artigo $8^{\circ}$, modalidade inovadora de desapropriação, relacionada ao descumprimento de uma função social.

A desapropriação urbanística sancionatória, por ser medida extraordinária, somente tem amparo constitucional e legal à medida em que seja utilizada como punição àqueles que optem por descumprir a exigência de se conferir a determinada propriedade privada o respeito a uma função social e desde que precedida do descumprimento de determinação de 
parcelamento ou edificação compulsórios, em um primeiro momento, e de pagamento de IPTU progressivo no tempo, em seguida.

Dessa maneira, ocorrendo em último caso e como forma de punição, não existe, por parte do poder público, destinação pré determinada para aquela propriedade. Assim, embora não se possa exigir, à luz do ordenamento jurídico brasileiro, que o Município, de forma vinculante, destine tais propriedades para a concretização do direito social à moradia em seu território, pode-se defender que atue prioritariamente nesse sentido.

Por fim, o direito à moradia, previsto de forma expressa na Lei Maior desde 2002, garante a todos os indivíduos uma residência digna. O pleno exercício desse direito é fator imprescindível a qualquer indivíduo para o gozo de uma existência digna, devendo o poder público valer-se de todos os instrumentos legais à sua disposição para concretizá-lo.

\section{REFERÊNCIAS}

ARENDT, Hannah. A condição humana. Tradução de Roberto Raposo, posfácio de Celso Lafer. 10. ed. Rio de Janeiro: Forense Universitária, 2007.

BONAVIDES, Paulo. Curso de direito constitucional. 33. ed. atual. São Paulo: Malheiros, 2018.

BRASIL. Decreto n. 591, de 6 de julho de 1992. Promulga o Pacto Internacional sobre Direitos Econômicos, Sociais e Culturais. Disponível em:

<http://www.planalto.gov.br/ccivil_03/decreto/1990-1994/d0591.htm>. Acesso em: 5 dez. 2019.

BRASIL. Constituição da República Federativa do Brasil de 1988. Promulgada em 5 de outubro de 1988. Disponível em:

<http://www.planalto.gov.br/ccivil_03/constituicao/constituicao.htm>. Acesso em: 4 dez. 2019.

BRASIL. Constituição Política do Império do Brasil. Outorgada em 25 de março de 1824. Disponível em: <http://www.planalto.gov.br/ccivil_03/constituicao/constituicao24.htm>. Acesso em: 4 dez. 2019.

BRASIL. Constituição da República dos Estados Unidos do Brasil. Promulgada em 24 de fevereiro de 1891. Disponível em:

<http://www.planalto.gov.br/ccivil_03/constituicao/constituicao91.htm>. Acesso em: 4 dez. 2019.

BRASIL. Lei n. 4.132, de 10 de setembro de 1962. Define os casos de desapropriação por interesse social e dispõe sobre sua aplicação. Disponível em:

<http://www.planalto.gov.br/ccivil_03/LEIS/L4132.htm>. Acesso em: 5 dez. 2019. 
BRASIL. Decreto n. 4.377, de 13 de setembro de 2002. Promulga a Convenção sobre a eliminação de todas as formas de discriminação contra a mulher, de 1979, e revoga o Decreto n. 89.460, de 20 de março de 1984. Disponível em:

<http://www.planalto.gov.br/ccivil_03/decreto/2002/D4377.htm>. Acesso em: $10 \mathrm{dez} 2019$.

BRASIL. Lei n. 10.406, de 10 de janeiro de 2002. Institui o Código Civil. Disponível em: <http://www.planalto.gov.br/ccivil_03/leis/2002/110406.htm>. Acesso em: 5 dez. 2019.

BRASIL. Lei n. 10.257, de 10 de julho de 2001. Regulamenta os arts. 182 e 183 da Constituição Federal, estabelece diretrizes gerais da política urbana e dá outras providências.. Disponível em: <http://www.planalto.gov.br/ccivil_03/LEIS/LEIS_2001/L10257.htm>. Acesso em: 5 dez. 2019.

COULANGES, Fustel de. A cidade antiga. Tradução de Frederico Ozanam Pessoa de Barros. São Paulo: Editora das Américas, 2006.

CARVALHO FILHO, José dos Santos. Propriedade, política urbana e Constituição. In: Revista da EMERJ, v. 6, n. 23, 2003. Disponível em: <http://www.emerj.tjrj.jus.br/revistaemerj_online/edicoes/revista23/revista23_168.pdf>. Acesso em: 5 dez. 2019.

DECLARAÇÃO Universal dos Direitos Humanos, de 10 de dezembro de 1948. Disponível em: 〈https://nacoesunidas.org/wp-content/uploads/2018/10/DUDH.pdf〉. Acesso em: 3 dez. 2019.

DINIZ, Maria Helena. Curso de Direito Civil Brasileiro. Direito das Coisas. v. 4. 28. ed. São Paulo: Saraiva, 2014.

DI PIETRO, Maria Sylvia Zanella. Direito Administrativo. 27. ed. São Paulo: Atlas, 2014.

FACHIN, Luiz Edson. Teoria crítica do direito civil. Rio de Janeiro: Renovar. 2003.

FILHO, José dos Santos Carvalho. Propriedade, política urbana e Constituição. Revista da EMERJ, v. 6, n. 23, 2003.

HOBSBAWM, Eric J. A era das revoluções. Tradução de Maria Tereza Lopes Teixeira e Marcos Penchel. 23. ed. São Paulo: Paz e terra, 2008.

HOLANDA, Sérgio Buarque de. Raízes do Brasil. 26. ed. São Paulo: Companhia das Letras, 1995.

IPEA. Estudo aponta redução do déficit habitacional no país. Disponível em: <http://www.ipea.gov.br/portal/index.php?option=com_content\&view=article\&id=20656>. Acesso em: 3 dez. 2019.

KELSEN, Hans. Teoria pura do direito. Tradução de João Baptista Machado. 6. ed. São Paulo: Martins Fontes, 1998.

$\mathrm{KICH}$, Bruno Canísio. A propriedade na ordem jurídica econômica e ideológica. Porto Alegre: Sergio Antonio Fabris Editor, 2004. 
LEAL, Rogério Gesta. A função social da propriedade e da cidade no Brasil: aspectos jurídicos e políticos. Porto Alegre: Livraria do Advogado; Santa Cruz do Sul: Edunisc, 1998.

. Comentário ao artigo 182, § 4. In: CANOTILHO, J. J. Gomes; MENDES, Gilmar F.; SARLET, Ingo W.; STRECK, Lenio L. (Coords.). Comentários à Constituição do Brasil. São Paulo: Saraiva/Almedina, 2013.

LEI Fundamental da República Federal da Alemanha. Promulgada em 23 de maio de 1949. Disponível em: <https://www.btg-bestellservice.de/pdf/80208000.pdf>. Acesso em: 6 dez. 2019.

MARINELA, Fernanda. Direito Administrativo. 7. ed. Niterói: Impetus, 2013.

MEIRELLES, Hely Lopes. Direito Administrativo Brasileiro. 38. ed. São Paulo: Malheiros, 2012.

Direito Municipal Brasileiro. 16. ed. atual. São Paulo: Malheiros Editores,

2008 .

MIRANDA, Pontes de. Tratado de direito privado. Direito das Coisas. Propriedade. Aquisição da propriedade imobiliária. tomo XI. atual. São Paulo: Bookseller, 2002.

NANNI, Giovanni Ettore. A evolução do direito civil obrigacional: a concepção do direito civil constitucional e a transição da autonomia da vontade para a autonomia privada. In: LOTUFO, Renan. (coord.). Cadernos de Direito Civil Constitucional. Curitiba: Juruá Editora.

NETO, Eugênio Facchini. Comentário ao artigo 170, III. In: CANOTILHO, J. J. Gomes; MENDES, Gilmar F.; SARLET, Ingo W.; STRECK, Lenio L. (coords.). Comentários à Constituição do Brasil. São Paulo: Saraiva/Almedina, 2013.

PEREIRA, Caio Mário da Silva. Instituições de direito civil. Direitos reais. v. IV. 22. ed. rev. atual. por Carlos Edison do Rêgo Monteiro Filho. Rio de Janeiro: Forense, 2014.

PINTO, Victor Carvalho. Direito urbanístico: plano diretor e direito de propriedade. 3. ed. rev. e atual. São Paulo: Editora Revista dos Tribunais, 2011.

ROSENVALD, Nelson. O direito de laje e a tridimensionalidade da propriedade. In: Transformações no Direito Privado nos 30 anos da Constituição: estudos em homenagem a Luiz Edson Fachin. Ehrhardt Júnior, Marcos; Cortiano Júnior, Eroulths (coords.). Belo Horizonte: Fórum, 2019.

SILVA, José Afonso da. Direito urbanístico brasileiro. 6. ed. rev. atual. São Paulo: Malheiros Editores, 2010.

SUNDFELD, Carlos Ari. O Estatuto da Cidade e suas Diretrizes Gerais. In: DALLARI, Adilson Abreu; FERRAZ, Sérgio. (coords.). Estatuto da Cidade: Comentários à Lei Federal 10.257/2001. 3. ed. atual. São Paulo: Malheiros Editores, 2013. 
TARTUCE, Flávio. Direito Civil: Direito das Coisas. v. 4. 6. ed. rev. atual. ampl. Rio de Janeiro: Forense; São Paulo: Método, 2014. 